\title{
Pencabutan Izin Usaha dan Likuidasi Bank
}

\author{
Nitya Yuki Mahya \\ nityayukimahya@yahoo.com
}

abstrak. Pencabutan izin usaha dilakukan sebagai langkah terakhir dalam upaya penyehatan bank apabila kesulitan bank mengganggu kelangsungan usahanya atau membahayakan sistem perbankan. Hal tersebut merupakan amanat dari UU Nomor 7 Tahun 1992 tentang Perbankan sebagaimana telah diubah dengan UU Nomor 10 Tahun 1998. Tulisan ini memuat mengenai bagaimana tahapan pencabutan izin usaha dan likuidasi terhadap suatu bank serta masalah yang mungkin dihadapi bank yang menjadi sebab dicabut izin usahanya oleh OJK dan dilikuidasi oleh LPS.

\section{Kata Kunci: Pencabutan Izin Usaha, Likuidasi Bank, Bank}

\section{PENDAHULUAN}

Sektor ekonomi di Indonesia merupakan salah satu sektor yang berperan penting, dan perkembangan kehidupan ekonomi rakyat secara alamiah mendorong dibutuhkannya lembaga-lembaga keuangan. Banyak lembaga keuangan yang bermunculan guna melayani kebutuhan masyarakat kecil, yang walaupun penekanan sasaran pelayanannya berbeda, tetapi semuanya mempunyai kesamaan fungsi, sebagai intermediasi keuangan. Menurut Surat Keputusan Menteri Keuangan Republik Indonesia Nomor 792 Tahun 1990 Tentang Lembaga Keuangan, Lembaga Keuangan adalah semua badan yang kegiatannya di bidang keuangan, melakukan penghimpunan dan penyaluran dana kepada masyarakat guna membiayai investasi perusahaan, konsumsi, serta kegiatan distribusi barang dan jasa. Lembaga keuangan, berdasarkan kemampuannya untuk menghimpun dana dari masyarakat secara langsung, dibagi menjadi 2 (dua), yaitu Lembaga Keuangan Bank yang terdiri dari Bank Umum dan Bank Perkreditan Rakyat, dan Lembaga Jasa Keuangan lainnya yang melaksanakan kegiatan di sektor Perasuransian, Dana Pensiun, Lembaga Pembiayaan (Leasing, Anjak Piutang dan Modal Ventura), dan perusahaan yang bergreak di bidang Pasar Modal misalnya perusahaan efek). Keduanya memiliki keterkaitan satu sama lain sebagai penyedia kredit dan sumber pendanaan sehingga dengan berjalannya kedua lembaga keuangan tersebut dengan baik dan beriringan, tujuan perekonomian nasional yang tercantum dalam UUD 1945 akan tercapai, mengingat pembangunan nasional memerlukan sumber pendanaan yang tidak kecil guna mencapai sasaran-sasarannya, antara lain: pertumbuhan ekonomi, pendapatan perkapita, kesempatan kerja, distribusi pendapatan, dan lain-lain. Upaya untuk memperbaiki dan memperkuat sektor keuangan khususnya industri perbankan pun menjadi sangat penting, supaya dapat mencapai sasaran tersebut. Perbankan adalah segala sesuatu yang menyangkut tentang bank, mencakup kelembagaan, kegiatan usaha, serta cara dan proses dalam melaksanakan kegiatan usahanya.

Untuk mewujudkan perekonomian nasional serta sistem keuangan yang dapat tumbuh secara berkelanjutan dan stabil diperlukan kegiatan di dalam sektor jasa keuangan yang terselenggara secara teratur, adil, transparan dan akuntabel, dan yang mampu melindungi kepentingan konsumen maupun masyarakat. Mengingat pentingnya fungsi perbankan di sektor perekonomian, kegiatan perbankan perlu diawasi oleh Otoritas Pengawasan. Menurut Pasal 29 ayat (1) Undang-Undang Nomor 7 Tahun 1992 Tentang Perbankan sebagaimana telah diubah dengan Undang-Undang Nomor 10 Tahun 1998, yang selanjutnya disebut UU Perbankan, pengawasan dan pembinaan bank dilakukan oleh Bank Indonesia, yang selanjutnya disebut BI.

Lazimnya, BI sebagai bank sentral diberikan kewenangan untuk memelihara sistem pembayaran dan mengawasi bankbank. Bentuk-bentuk pembinaan dan pengawasan yang dilakukan BI terhadap bank dapat bersifat preventif dalam bentuk 
ketentuan-ketentuan, petunjuk dan nasihat, bimbingan dan pengarahan, maupun secara represif dalam bentuk pemeriksaan yang disusul dengan tindakan-tindakan perbaikan, sehingga pada akhirnya BI dapat menetapkan arah pembinaan dan pengembangan bank, baik secara individual maupun secara keseluruhan.

\section{KAJIAN PUSTAKA}

Tugas pengawasan bank oleh BI selain berdasarkan UU Perbankan juga diamanatkan oleh Undang-Undang Nomor 23 Tahun 1999 Tentang Bank Indonesia sebagaimana telah diubah dengan Undang-Undang Nomor 6 Tahun 2009, yang selanjutnya disebut UU BI, khususnya Pasal 8 huruf $\mathrm{c}$ tentang pengawasan. Namun demikian, berdasarkan Pasal 34 ayat (1) UU BI, fungsi pengawasan Bank diamanatkan untuk dialihkan kepada lembaga pengawas sektor jasa keuangan independen dan dibentuk berdasarkan Undang-Undang tersendiri. Pada tanggal 22 November 2011 terbitlah Undang-Undang yang dimaksud yaitu Undang-Undang Nomor 21 Tahun 2011 tentang Otoritas Jasa Keuangan, yang selanjutnya disebut UU OJK. Sejak tanggal 31 Desember 2012, berdasarkan Pasal 55 ayat (1) UU OJK, fungsi, tugas dan wewenang pengaturan dan pengawasan kegiatan jasa keuangan di sektor Pasar Modal, Perasuransian, Dana Pensiun, Lembaga Pembiayaan dan Lembaga Jasa Keuangan Lainnya beralih dari Badan Pengawas Pasar Modal dan Lembaga Keuangan-Kementerian Keuangan ke Otoritas Jasa Keuangan (yang selanjutnya disebut OJK). Sementara itu, fungsi, tugas dan wewenang pengaturan dan pengawasan kegiatan jasa keuangan di sektor perbankan efektif beralih dari BI ke OJK sejak 31 Desember 2013, berdasarkan Pasal 55 Ayat (2) UU OJK. Hal tersebut ditegaskan dalam Pasal 69 UU OJK yang menyatakan bahwa fungsi, tugas, dan wewenang BI beralih menjadi fungsi, tugas, dan wewenang OJK. Selanjutnya terkait dengan peraturanperaturan perbankan yang telah ada, berdasarkan Pasal 70 UU OJK diatur bahwa sejak UU OJK berlaku, peraturan perundangundangan di sektor jasa keuangan dinyatakan tetap berlaku sepanjang tidak bertentangan dan belum diganti berdasarkan UU OJK. Hal ini dilakukan dengan maksud agar tidak terjadi kekosongan hukum.

Pengaturan dan pengawasan mengenai kelembagaan, kesehatan, aspek kehati-hatian, dan pemeriksaan bank secara individual merupakan lingkup pengaturan dan pengawasan microprudential yang menjadi tugas dan wewenang OJK. Adapun lingkup pengaturan dan pengawasan macroprudential bank secara industri atau nasional, sistem pembayaran, dan moneter tetap merupakan tugas dan wewenang BI. Dalam pelaksanaan pengaturan dan pengawasan bank agar harmonis, OJK berkoordinasi dengan BI dan sebaliknya.

Fungsi utama perbankan Indonesia yaitu sebagai penghimpun dan penyalur dana masyarakat, dengan kata lain fungsi perbankan adalah sebagai lembaga intermediasi yaitu perantara antara pihakpihak yang memiliki kelebihan dana dengan pihak-pihak yang kekurangan atau membutuhkan dana. Melihat jenisnya, bank di Indonesia dibagi menjadi dua, yaitu Bank Umum dan Bank Perkreditan Rakyat. Bank umum adalah bank yang melaksanakan kegiatan usaha secara konvensional atau berdasarkan prinsip syariah yang dalam kegiatannya memberikan jasa dalam lalu lintas pembayaran, sedangkan Bank Perkreditan Rakyat, yang selanjutnya disebut BPR, adalah bank yang melaksanakan kegiatan usaha secara konvensional atau berdasarkan prinsip syariah yang dalam kegiatannya tidak memberikan jasa dalam lalu lintas pembayaran.

Dalam pelaksanaannya kegiatan usahanya, bank harus didasari dengan prinsip kepercayaan dan kehati-hatian, mengingat industri perbankan merupakan industri yang sangat bertumpu pada kepercayaan masyarakat yang memiliki uang yang disimpan di bank. Kepercayaan masyarakat bagi industri perbankan adalah segalanya. Dengan adanya kepercayaan dari masyarakat yang kemudian menjadi nasabah, suatu bank akan bertahan hidup dan berkrembang. Prinsip kehati-hatian adalah suatu asas atau prinsip yang menyatakan bahwa bank dalam menjalankan fungsi dan kegiatan usahanya wajib bersikap hati-hati dalam rangka 
melindungi dana masyarakat yang dipercayakan padanya. Dengan dilaksanakannya prinsip ini maka bank akan tetap sehat, berkembang dan terhindar dari likuidasi.

Seperti halnya dalam pemberian kredit atau pembiayaan oleh bank, terdapat resiko kegagalan atau kemacetan dalam pelunasannya, sehingga dapat berpengaruh terhadap kondisi keuangan atau kesehatan bank. Faktor yang dapat mempengaruhi tingkat kesehatan bank adalah faktor permodalan, kualitas aset, manajemen, rentabilitas, likuiditas, dan sensitivitas terhadap resiko pasar atau yang dikenal dengan singkatan CAMEL (Capital, Asset, Management, Earning, Liquidity). Permasalahan dan kondisi keuangan bank yang buruk dapat menimbulkan terjadinya likuidasi bank. Pengurus bank bertanggungjawab untuk menyelesaikan permasalahan dan memperbaiki kondisi keuangan bank yang buruk agar kembali sehat dan hal itu menjadi perhatian dan pengawasan OJK karena bank yang tidak sehat akan berdampak pada berkurangnya kepercayaan masyarakat terhadap bank tersebut.

Salah satu cara OJK mewujudkan perbankan yang sehat ialah dengan menerbitkan berbagai ketentuan kehati-hatian yang berlaku bagi kegiatan perbankan. Ketentuan kehati-hatian tersebut misalnya terkait dengan ketentuan mengenai tingkat kesehatan. Bank wajib memelihara tingkat kesehatan bank sesuai dengan ketentuan kecukupan modal, kualitas aset, kualitas manajemen, likuiditas, rentabilitas, solvabilitas, dan aspek lain yang berhubungan dengan usaha bank, dan wajib melakukan kegiatan usaha sesuai dengan prinsip kehatihatian. Ketidaksehatan bank dapat terjadi karena pengelolaan atau manajemen yang tidak hati-hati. Apabila suatu bank menjadi tidak sehat, direksi bertugas untuk dapat menyehatkan kembali bank dengan melakukan berbagai upaya perbaikan atas kelemahan atau permasalahan dengan diawasi pelaksanaannya oleh dewan komisaris.

\section{HASIL DAN PEMBAHASAN}

Dalam hal ini, OJK sebagai otoritas melakukan pengawasan bank sebagai pengawas eksternal sedangkan pengawasan internal dilakukan oleh komisaris supaya tidak terjadi pelanggaran ketentuan dan bank dapat berkembang dengan baik. Jika bank tidak kunjung berkembang, terdapat kemungkinan adanya kesalahan, pelanggaran atau kelemahan pada bank tersebut, misalnya direksi tidak dapat mengelolanya dengan baik, atau karena banyak terjadi kredit macet yang semakin besar sehingga terjadi kerugian dan dibebankan pada modal yang menyebabkan turunnya modal. Tingkat kesehatan bank dapat diketahui secara sederhana dengan melihat tersedianya rasio kecukupan modal yang dikenal dengan Kewajiban Penyediaan Modal Minimum (yang selanjutnya disingkat KPMM) sebesar prosentase tertentu misalnya, untuk BPR KPMM yang sehat minimal $4 \%$ dan untuk Bank Umum adalah $8 \%$.

KPMM adalah rasio Modal terhadap Aset Tertimbang Menurut Risiko, yang selanjutnya disingkat ATMR, yang wajib dicapai oleh BPR sebagaimana diatur dalam peraturan OJK. KPMM menunjukan kemampuan perbankan untuk menyerap atau mengatasi kerugian, semakin tinggi presentase rasio KPMM menunjukkan tingkat kesehatan bank semakin baik, karena bank memiliki modal yang besar. Sebaliknya, semakin rendah rasio KPMM, tingkat kesehatan bank semakin buruk, karena modal bank kecil dan apabila terus-menerus mengalami kerugian, modal bank akan berkurang, sehingga pada akhirnya akan mengalami kesulitan permodalan dan pemegang saham yang ada atau investor (pemodal baru) harus menambah modal agar bank tetap dapat beroperasi dengan baik.

OJK melakukan pengawasan normal sejak bank didirikan dan berjalan dengan baik. Bank tidak lagi mendapatkan pengawasan yang normal tetapi pengawasan intensif apabila bank mengalami permasalahan terkait permodalan dan likuiditas. Bila permasalahan permodalan dan likuiditas memburuk dalam jangka waktu tertentu dan tidak dapat diperbaiki, pengawasan bank akan diperketat lagi dengan pengawasan khusus. Dengan demikian, dalam rangka menjalankan tugas pengawasan terhadap BPR, OJK menetapkan tiga tahap pengawasan yaitu Pengawasan 
normal, Pengawasan intensif dan Pengawasan khusus.

Tahap pengawasan intensif merupakan tambahan tahapan pengawsan terhadap BPR yang diatur dalam Peraturan Otoritas Jasa Keuangan Nomor 19/POJK.03/2017 tentang Penetapan Status dan Tindak Lanjut Pengawasan Bank Perkreditan Rakyat dan Bank Perkreditan Rakyat Syariah, yang selanjutnya disebut POJK 19, yang menyempurnakan peraturan sebelumnya yang berupa Peraturan Bank Indonesia Nomor 11/20/PBI/2009 tentang Tindak Lanjut Penanganan Terhadap Bank Perkreditan Rakyat Dalam Status Pengawasan Khusus, yang selanjutnya disebut PBI 11 , yang hanya mengatur pengawasan BPR dengan tahapan pengawasan normal dan pengawasan khusus.

Dalam hal BPR ditetapkan dalam status pengawasan khusus oleh OJK, BPR disamping harus melakukan perbaikan terhadap permasalahan yang terjadi dalam jangka waktu 180 hari, BPR juga dilarang melakukan kegiatan tertentu yang dapat menyebabkan kondisi bank memburuk. Misalnya larangan untuk menerima simpanan baru dan/atau kredit baru. Melainkan BPR harus memperbaiki kekurangan yang terjadi di Bank itu terlebih dahulu, dengan jangka waktu yang diberikan tersebut. Terutama dengan cara menambah dana segar berupa setoran modal ari pemegang saham atau mengundang investor. Selanjutnya, OJK menginformasikan kepada Lembaga Penjamin Simpanan, yang selanjutnya disebut LPS, apabila bank yang bermasalah tersebut, sedang dalam upaya penyehatan oleh OJK.

Apabila setelah direksi/pemegang usaha melakukan upaya-upaya terhadap BPR untuk mengeluarkan dari status pengawasan khusus tidak berhasil, BPR dinyatakan tidak dapat disehatkan oleh OJK dan dinyatakan sebagai bank gagal untuk kemudian diserahkan kepada LPS untuk menanganinya sesuai dengan kewenangan yang dimiliki LPS.

Berdasarkan Undang-Undang Nomor 24 Tahun 2004 Tentang Lembaga Penjamin Simpanan sebagaimana telah diubah UndangUndang Nomor 7 Tahun 2009, yang selanjutnya disebut UU LPS, dalam Pasal 22 ayat (1), LPS berwenang menangani bank gagal yaitu untuk menyelamatkan atau tidak menyelamatkan bank tersebut. Apabila LPS memutuskan untuk tidak melakukan penyelamatan, Bank tersebut akan dicabut izin usahanya oleh OJK. Kewenangan tersebut tertuang dalam Pasal 9 huruf h UU OJK, yaitu bahwa untuk melaksanakan tugas pengawasan, OJK mempunyai wewenang memberikan dan/atau mencabut Izin usaha. Setelah pencabutan izin usaha dilanjutkan dengan pembubaran badan hukum bank dan proses likuidasi. Proses likuidasi dilakukan setelah bank yang dicabut izin usahanya diserahkan OJK kepada LPS, berdasarkan Pasal 14 ayat (2) PBI 11.

\section{SIMPULAN}

Kewenangan OJK untuk mencabut izin usaha BPR terdapat dalam Pasal 37 ayat (2) UU Perbankan, yang menetapkan 2 (dua) alasan hukum yang memungkinkan suatu bank dicabut izin usahanya oleh OJK, yaitu apabila menurut penilaian OJK:

1. Keadaan suatu bank membahayakan sistem perbankan, termasuk dalam kriteria yang membahayakan sistem perbankan adalah apabila tingkat kesulitan yang dialami dalam melakukan kegiatan usaha, suatu bank tidak mampu memenuhi kewajiban-kewajibannya kepada bank lain, sehingga pada gilirannya akan menimbulkan dampak berantai kepada bank-bank lainnya (Penjelasan atas Pasal 37 ayat (2) Undang-Undang Nomor 7 Tahun 1992 sebagaimana telah diubah dengan Undang-Undang Nomor 10 Tahun 1998); atau

2. Suatu bank mengalami kesulitan yang membahayakan kelangsungan usahanya dan tindakan untuk mengatasinya belum cukup untuk mengatasi kesulitan yang dihadapi bank. Termasuk dalam kriteria bahwa "suatu bank mengalami kesulitan yang membahayakan kelangsungan usahanya" adalah apabila berdasarkan penilaian dari BI, kondisi usaha bank semakin memburuk, antara lain ditandai dengan menurunnya permodalan, kualitas aset, likuiditas dan rentabilitas, serta pengelolaan bank yang tidak dilakukan berdasarkan prinsip kehati-hatian (Prudential banking) dan asas perbankan 
yang sehat. (Penjelasan atas Pasal 37 ayat (1) Undang-Undang Nomor 7 Tahun 1992 sebagaimana telah diubah dengan Undang-Undang Nomor 10 Tahun 1998).

Selanjutnya setelah BPR dicabut izin usahanya oleh OJK, LPS membubarkan badan hukum bank dan membentuk tim likuidasi dengan tugas melaksanakan likuidasi yaitu melaksanakan pemberesan hak dan kewajiban bank terhadap kreditur dan nasabah BPR (nasabah penyimpan dan nasabah debitur). Likuidasi BPR pada umumnya terjadi karena jumlah kewajiban yang dimiliki lebih besar dibanding dengan kekayaan atau asetnya, kecuali likuidasi atas permintaan dari pemegang saham itu sendiri atau self liquidation. Self liquiation terjadi karena semata-mata pemegang saham tidak lagi ingin menjalankan kegiatan usaha bank walaupun masih mampu menyelesaikan segala kewajiban bank dengan kekayaan bank sendiri, tidak menggunakan dana penjaminan LPS. Pengertian Likuidasi dalam Pasal 1 Angka 13 Peraturan Lembaga Penjamin Simpanan Nomor 1/PLPS/2011 tentang Likuidasi Bank sebagaimana telah diubah dengan Peraturan Lembaga Penjamin Simpanan Nomor 1/PLPS/2012, yang selanjutnya disebut PLPS 1, adalah tindakan penyelesaian seluruh aset dan kewajiban bank sebagai akibat pencabutan izin usaha dan pembubaran badan hukum bank. Likuidasi bank merupakan kelanjutan dari tindakan pencabutan izin usaha dan pembubaran badan hukum bank. Pelaksanaan likuidasi bank dilakukan oleh Tim Likuidasi yang dibentuk oleh LPS, dimana direksi Bank yang lama dinon-aktifkan, tetapi masih harus membantu tim likuidasi untuk menyelesaikan hak dan kewajibannya. Dengan terbentuknya Tim Likuidasi, tanggung jawab dan kepengurusan bank dalam likuidasi dilakukan oleh Tim Likuidasi. Berdasarkan Pasal 10 huruf g PLPS 1, dalam melaksanakan tugasnya Tim Likuidasi berwenang mewakili bank dalam likuidasi di segala hal yang berkaitan dengan penyelesaian hak dan kewajiban bank tersebut. Pelaksanaan likuidasi bank wajib diselesaikan dalam jangka waktu paling lambat 2 (dua) tahun terhitung sejak tanggal dibentuknya Tim Likuidasi dan dapat diperpanjang 2 (dua) kali masing-masing paling lama 1 (satu) tahun, menurut Pasal 14 ayat (1) dan ayat (2) PLPS 1.

\section{DAFTAR PUSTAKA}

Undang-Undang Nomor 21 Tahun 2011 Tentang Otoritas Jasa Keuangan.

Undang-Undang Nomor 24 Tahun 2004 Tentang Lembaga Penjamin Simpanan sebagaimana telah diubah UndangUndang Nomor 7 Tahun 2009, Pasal 21 ayat (1)

Undang-Undang Nomor 7 Tahun 1992 tentang Perbankan sebagaimana diubah dengan Undang-Undang Nomor 10 Tahun 1998.

Peraturan Otoritas Jasa Keuangan Nomor 19/POJK.03/2017 tentang Penetapan Status dan Tindak Lanjut Pengawasan Bank Perkreditan Rakyat dan Bank Perkreditan Rakyat Syariah.

Peraturan Lembaga Penjamin Simpanan Nomor 1/PLPS/2011 tentang Likuidasi Bank.

Peraturan Bank Indonesia Nomor 11/20/PBI/2009 tentang Tindak Lanjut Penanganan Terhadap Bank Perkreditan Rakyat Dalam Status Pengawasan Khusus

Peraturan Bank Indonesia Nomor 9/17/PBI/2007 tentang Sistem Penilaian Tingkat Kesehatan Bank Umum

Adrian Sutedi, Hukum Perbankan (Suatu Tinjauan Pencucian Uang, merger, Likuidasi, dan Kepailitan), (Jakarta: Sinar Grafika, 2008).

Hermansyah, Hukum Perbankan Nasional Indonesia, (Jakarta: Prenada Media, 2011).

Kusumaningtuti SS, Peranan Hukum dalam Penyelesaian Krisis Perbankan di Indonesia, (Jakarta: Raja Grafindo Persada, 2009).

Mandala Manurung dan Prathama Rahardja, Uang, Perbankan, dan Ekonomi Moneter (Kajian Kontekstual Indonesia) (Jakarta:Penerbitan Fakultas Ekonomi Universitas Indonesia, 2004).

Rachmadi Usman, Aspek-aspek hukum Perbankan di Indonesia, (Jakarta: PT. Gramedia Pustaka Utama, 2003). 
Hikmanto Juwana, "Analisis Ekonomi atas Hukum Perbankan" Jurnal Hukum dan Pembangunan, Edisi Nomor 1-3 Tahun XXVIII Januari-Juni 1998. 